\title{
Ants of the southern Carnarvon Basin, Western Australia: An investigation into patterns of association
}

\author{
N. R. Gunawardene and J. D. Majer \\ Department of Environmental Biology, Curtin University of Technology, \\ GPO Box U1987, Bentley, WA 6845
}

\begin{abstract}
A study of the ant species of the southern Carnarvon Basin was carried out in order to identify the patterns of species distribution and associations across a transitional landscape. The study yielded 35 genera and 243 species of ants, $58 \%$ of which were positively identified and the remaining placed into species complexes. Twelve assemblages of associated species were found, with members having a predominantly arid zone biogeographic distribution, with some southern elements. The suggestion by Gibson et al. (2000) to push the boundary of the South-west Province more south and west was supported by the ant species in this study, as there were more arid zone affinities in two scuthern sites of the study area. Species assemblages were positively associated with temperature, rainfall, longitude and altitude, but genus assemblages yielded a more latitudinal association.
\end{abstract}

Key words: Ant species, ant genera, species associations, biogeographic origin.

\section{INTRODUCTION}

Biological inventorying and monitoring is an important part of environmental management; it allows those involved to make responsible decisions regarding biodiversity and ecosystem functioning (Stork and Samways 1995). Incorporation of biodiversity survey data with geographical data should provide the basis for understanding broadscale patterns across ecosystems, while at the same time establishing comprehensive databases for flora and fauna. These databases could then be utilized in environmental assessment procedures, in rapid biodiversity assessment studies and to provide support for gazetting areas for conservation (Greenslade 1985, McKenzie et al. 1989, Kremen et al. 1993, Oliver and Beattie 1993, Stork and Samways 1995).

Invertebrates are increasingly being incorporated into biological surveys as they play major roles in ecosystem functioning (McGeoch 1998). Often, due to the scale of invertebrate collections, indicator or surrogate taxa are chosen for facilitating rapid assessment of environments (Oliver and Beattie 1996, Lawton et al. 1998). Ants are often selected as they are easily collected and are involved in a variety of ecosystem functions (Alonso 2000), such as seed dispersal (Drake 1981); predator-prey interactions (Rossbach and Majer 1983); nutrient cycling (Greenslade and Thompson 1981); and in the maintenance of soil quality (Lobry De Bruyn 1999). Studies on the patterns of their distribution can contribute to a better understanding of the biogeographic characteristics of the environment within which they live (Fisher 1999).

The Australian ant fauna has been noted as one of the most complex groups in Australia and has also been ranked as one of the richest known ant faunas in the world (Greenslade and Greenslade 1989, Andersen and Burbidge 1992, Andersen 1993, Shattuck 1999). Out of the 21 subfamilies recognised in the world (Bolton 2003), 13 are found in Australia, containing 100 genera, and 1275 described species (Shattuck 1999), with at least as many again undescribed species (Majer et al. 2004). This abundance of species identifies ants as a major influence in the functioning of any habitat.

Comprehensive studies of the Western Australian (WA) ant fauna have been carried out in some regions of the State, but the information available remains fragmented. To date, due to a paucity of research in many areas of WA, a thorough list or map of species occurrences is unavailable. Studies of Australia's arid zone have revealed high species richness compared to arid zones in other regions of the world (Morton 1982, Andersen 1997). Also, research in specific regions such as the semi-arid areas to the south, has demonstrated a great diversity of species (Andersen and Burbidge 1992). This indicates that WA should be home to a large diversity of ants, as the arid zone in the north and, semi-arid areas to the south cover a large percentage of it. 


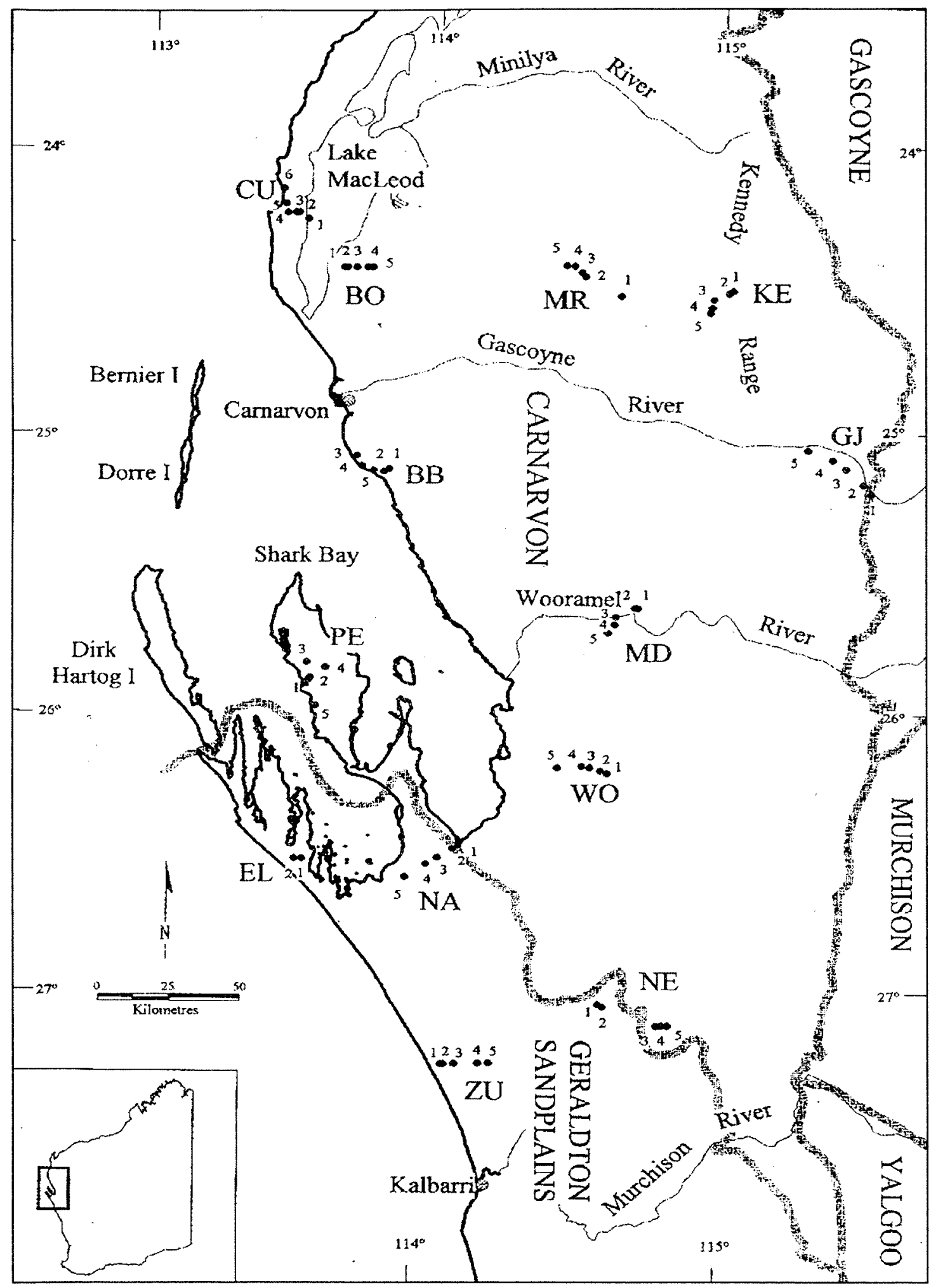

Figure 1 Map of the southern Carnarvon Basin study site, displaying the 13 survey areas and their corresponding quadrats that were investigated during the survey. Edel Land (EL) was the only area not included in the current study. The map also shows the major geographic boundaries that traverse the region.

Preliminary studies in and around the Carnarvon Basin suggest a highly diverse biota. However, until Environment Australia (EA), the Department of Conservation and Land Management (DCLM) and the Western Australian Museum (WAM) jointly carried out the comprehensive faunal and floristic study of the southern Carnarvon Basin, there was no survey that combined climatic and geological variables with biotic factors such as vegetation and invertebrate distribution. The 13 sites chosen for the study were largely distributed around the southern portion of the Basin, which included the crossover 
Table 1 Brief characteristics of the vegetation groups (Keighery et al. 2000).

\begin{tabular}{lll}
\hline Vegetation group & Quadrat & General characteristics \\
\hline $1-4$ & BB; BO; CU; GJ; KE3-5; MD; & Coastal and inland Acacia shrublands interspersed with \\
& MR1-2, 4-5; NA 1-2; PE1-4; WO & Eucalyptus or Melaleuca woodlands. \\
$5-6$ & KE1-2; MR3; NE1, 3-5; PE5 & Eucalyptus-Callitris woodlands or Eucalyptus-Acacia woodland \\
7 & NE2 & Banksia woodland \\
$8-9$ & NA3-5; ZU & Eucalyptus woodland \\
\hline
\end{tabular}

zones for the Eremaean and South-western Provinces (Burbidge et al. 2000). The book that resulted from this study included chapters on climate, geology, flora, various vertebrate groups and invertebrate groups such as spiders and centipedes.

This paper documents the ant species in the southern Carnarvon Basin (SCB) for 12 of the 13 sites, identifies species assemblages, and investigates how these relate to the geomorphologic and climatic variables in this region. It represents the first thorough inventory of ants in a transitional zone from the northern to the southern fauna, and contributes to a better understanding of the distributions and associations of the WA ant fauna.

\section{METHODS}

\section{Study area}

The ant species were collected as part of a large comprehensive floristic and faunal study carried out in a $75,000 \mathrm{~km}^{2}$ region of WA. The study area extended from the Cape Range in the Exmouth area (near the Minliya River) outwards to the Kennedy Range and Gascoyne Junction, with a southern extension to the Murchison River (Figure 1). The study area includes the Interim Biogeographic Regionalisation of Australia (IBRA) regions of the Geraldton Sand plains and the Carnarvon Region. The whole study area traverses Beard's Southwestern phytogeographic province (SWBP) in the south and the Eremaean province to the north (Burbidge et al. 2000).

These boundary areas represent the meeting of the arid and southern mesic areas of WA. The DCLM and WAM chose this area for their surveys in order to supplement and improve the knowledge of the patterns of distribution of plants and animals in this highly varied and ecologically significant system (Burbidge et al. 2000). In view of the high degree of variability within the region, 13 study sites were positioned in a stratified random array, stretching from Cape Cuvier to the north to the Zuytdorp cliffs in the south. The sites incorporated the typically northern Acacia shrub lands and the southern Eucalyptus woodlands and heaths, interspersed with hummock and tussock grasslands upon low dunes along the coastline (Keighery et al. 2000). These sites were coded as: BB- Bush Bay; BO-
Boolathana; CU- Cape Cuvier; EL- Edel Land; GJGascoyne Junction; KE- Kennedy Range; MAMardathuna; MD- Meedo; NA- Nanga; NE- Nerren Nerren; PE- Peron Peninsula; WO- Woodleigh; and ZU- Zuytdorp (Figure 1).

Each survey area contained five quadrats. Two exceptions were $\mathrm{CU}$, which had six quadrats and EL, which had only two. For the ant study, only 12 survey areas were analysed, as the samples from EL were unavailable. Each quadrat contained five traps, totalling 305 traps altogether.

\section{Vegetation}

The vegetation study conducted by Keighery et al. (2000) revealed nine major vegetational groups (Table 1). The vegetation assemblages of groups $1-4$ were the most species-rich and widespread across the study area. There was a high saline influence within the plots in group 1 (quadrats BB1, BB3, BO2, CU1 and PE2), with a number of Halosarcia and Atriplex species, which are saline-adapted. Group 6 differed from group 5 in that these quadrats were located on top of the Kennedy Range (MR3, KE1 and KE2). Group 7 was hypothesized to be a transitional zone between the Eucalyptus woodlands of group 5 and the limestone heaths of group 9 (Keighery et al. 2000). The last two groups, differed from each other in that group 8 had Eucalyptus woodlands over red dunes (NA 3-5), whereas group 9 (ZU1-5) was woodland over a limestone heath.

\section{Climate and geomorphology}

The climate of the region also reflects the variability in the landscape. Lying in a transitional region, the area is affected by the typical winter rainfall patterns of the southwest, as well as the monsoonal summer conditions of the north (Wyrwoll et al. 2000a). Geological and geomorphological patterns are described in Wyrwoll et al. (2000b) and are briefly characterised in Table 2. Ten regions and morphological features traverse the study area. Further details of each individual quadrat are described in Wyrwoll et al. (2000b).

\section{Field sampling}

Invertebrate pitfall traps were placed at 13 sites throughout the study area. Two types of pitfall 
Table 2 General geological and geomorphological patterns of each survey area (Wyrwoll et al. 2000b).

\begin{tabular}{ll}
\hline Survey Area & Geomorphological features \\
\hline CU and BO & $\begin{array}{l}\text { All quadrats in CU and BO were located in the MacLeod Region, comprised of marine and aeolian } \\
\text { alluvial sediments. The main morphological feature is Lake MacLeod, characterised by a number of } \\
\text { linear calcareous sand dunes and tidal flats. }\end{array}$
\end{tabular}

$\mathrm{BB}$ and $\mathrm{GJ}$

The Carnarvon Coastal Plain includes BB1-5 and GJ2-5 together. Although the sites are located on opposite sides of the study area, they are found to the south of the Gascoyne River, in the alluvial deposition of the Gascoyne River deltas. GJ1 sits outside this area in the Bidgemia Region furthest inland of all the sites.

$\mathrm{KE}$

The Kennedy Region includes all quadrats of KE and is characterised by extensive scree slopes around the plateau, cotnaining some of the largest sand dunes in the area.

MR

Quadrats MR2-5 fell into the Mardathuna Regions- mainly dune covered calcrete areas with associated coastal and riverine settings. MR1 falls into the more noncalcareous gradational soils of the Binthalya Region.

NA and PE Sites NA1-5 and PE1-5 are placed in the Peron Region, located in and around the coast of the Peron Peninsula. Linear dunes traverse the large undulating sand plains of the area with interdunal corridors containing evaporite pans (birridas).

MD, NE, WO The Victoria Plateau includes a variety of sites; these are MD4-5, NE1-5, WO 1-2, ZU3-5 and all

and $\mathrm{ZU} \quad$ generally characterised by gently undulating sand plains and small dune fields.

The Wooramel Region (MD1-3) is transitional between the Carnarvon Region and the Carbla Plateau. It has soils associated with the drainage valley of the Wooramel River.

The Carbla plateau (WO3-5) has well-developed limestone ridges that are similar to the Edel Region, containing EL1-2 and ZU1-2. The difference in the Edel Region is the type of limestone, which in this case is Tamala limestone with more yellow rather than red sands dominating the dune formations

traps were used. 'Wet' traps were $25 \mathrm{~L}$ buckets (300 $\mathrm{mm}$ diameter $\times 400 \mathrm{~mm}$ depth) dug into the ground, with the rim flush with the ground surface. Five $10 \mathrm{~cm}$ holes were then cut into the lids and a piece of chicken wire placed below the lid to allow vertebrates to escape. Each bucket contained approximately $3.5 \mathrm{~L}$ of a mix of ethylene glycol, formalin $(1 \%)$ and water $(10 \%)$. Five traps were placed at $5 \mathrm{~m}$ intervals along a transect at each quadrat. The traps were left open for one year from August 1994 to August 1995 and were cleared three times (September, January and May) prior to the final clearance at the end of the trapping period. All the samples were returned to the laboratory to be cleaned and stored in 75\% ethanol (Harvey et al. 2000).

'Dry' traps used to collect vertebrate fauna were located in the same quadrats but were slightly smaller (125mm diameter $\times 500 \mathrm{~mm}$ depth) and were connected by flywire drift fences (McKenzie $e t$ al. 2000). Two 5-day trapping efforts in September 1994 and May 1995 yielded a number of invertebrate samples as the traps were cleared daily during the 5-day period. All samples from these traps were stored in 75\% ethanol. All ant species were removed and sorted to species level. The species were then identified in the laboratory and restored to their permanent storage units. All specimens are lodged in the WAM collection, and vouchers of each species are lodged in the Curtin University of Technology Ant Collection.

The preserved samples available were the
October 1994 wet trap collection, October 1994 dry trap collection and July 1995 dry trap collection. Samples from the other collection periods (January, May and August 1995) and from the EL survey area were not available from WAM. Species that could not be positively identified to species level were placed into species complexes and assigned Australian National Insect Collection (ANIC) numbers or Curtin University Ant Collection (JDM) numbers for future identification.

\section{Data analysis}

All ant species were recorded as being either present or absent at any particular trap. Species occurrences from the wet and dry trap types were combined, as differences in sampling efforts could not be quantified. Only presence/absence data were analysed, as analyses of relative abundances of ant species are often problematic due to the tendency of the data to be spatially clumped and biased as a result of differences in sampling method and effort (Longino 2000). All species that occurred at only one quadrat ('uniques') were removed due to the uncertainty of whether these species were not caught by the sampling method or as a result of their actual rarity.

\section{Biogeographic affiliations}

Each species' biogeographic affiliation was determined using distribution criteria based on previous collections of the ant species across WA and Australia. In the case of new species, affiliations 
Table 3 List of all ant species collected and identified in the 1994-1995 southern Carnarvon Basin survey and their biogeographic distribution. Some species are listed under more than one biogeographic region due to uncertainty of their origin or because their range traverses more than one region. Species have been listed as widespread if they occur in all three biogeographic regions. \#Indicates new species to Curtin University Ant Collection.

\begin{tabular}{|c|c|c|c|c|c|}
\hline Subfamily & Species & Southern & Arid & Tropical & Widespread \\
\hline \multirow[t]{10}{*}{ Myrmeciinae } & Myrmecia callima (Clark) & & * & & \\
\hline & Myrmecia desertorum Wheeler & $*$ & * & & \\
\hline & Myrmecia elegans (Clark) & * & * & & \\
\hline & Myrmecia? elegans (Clark) \# & & * & & \\
\hline & Myrmecia hilli (Clark) & & * & & \\
\hline & Myrmecia urens gp. JDM sp. 1 & $*$ & & & . \\
\hline & Myrmecia nr. urens gp. JDM sp. 71 & * & & & \\
\hline & Myrmecia urens gp. JDM sp. 728 & $*$ & & & \\
\hline & Myrmecia ?varians Mayr \# & $*$ & * & & \\
\hline & Myrmecia sp. nr pilosula Smith & & * & & \\
\hline \multirow[t]{11}{*}{ Cerapachyinae } & Cerapachys brevicollis (Clark) & * & & & \\
\hline & Cerapachys brevis (Clark) & & & & * \\
\hline & Cerapachys clarki (Crawley) & $*$ & & & \\
\hline & Cerapachys fervidus (Wheeler) & & & & * \\
\hline & Cerapachys gilesi (Clark) & $*$ & & & \\
\hline & Cerapachys greavesi (Clark) & * & & & \\
\hline & Cerapachys incontentus Brown & & * & & \\
\hline & Cerapachys sjostedti Forel & * & * & & \\
\hline & Cerapachys JDM sp. 741 & & * & & \\
\hline & Cerapachys JDM sp. 1049 & & $*$ & & \\
\hline & Cerapachys JDM sp. 1103 & * & & & \\
\hline \multirow[t]{19}{*}{ Ponerinae } & Anochetus armstrongi MacAreavy & * & * & & \\
\hline & Leptogenys clarki Wheeler & & & & * \\
\hline & Leptogenys darlingtoni Wheeler & & * & & \\
\hline & Leptogenys nr. tricosa JDM sp. 1021 Taylor & & & * & \\
\hline & Odontomachus ruficeps Smith & & & & $*$ \\
\hline & Pachycondyla denticulata gp. JDM sp. 730 & & * & & \\
\hline & Pachycondyla lutea (Mayr) & & & & * \\
\hline & Pachycondyla piliventris regularis Forel & & $*$ & & \\
\hline & Rhytidoponera crassinoda (Forel) & & * & * & \\
\hline & Rhytidoponera dubia gp. JDM sp. 904 & & * & & \\
\hline & Rhytidoponera foveolata Crawley & * & $*$ & & \\
\hline & Rhytidoponera metallica (Smith) & & & & * \\
\hline & Rhytidoponera metallica gp. JDM sp. 1097 & & * & & \\
\hline & Rhytidoponera metallica gp. JDM sp. 1098 \# & & $*$ & & \\
\hline & Rhytidoponera micans Clark & & * & & \\
\hline & Rhytidoponera taurus (Forel) & & * & * & \\
\hline & Rhytidoponera tyloxys Brown and Douglas & & * & * & \\
\hline & Rhytidoponera violacea (Forel) & & & & * \\
\hline & Rhytidoponera JDM sp. 736 & & $*$ & & \\
\hline \multirow[t]{19}{*}{ Myrmicinae } & Anisopheidole antipodum (Smith) & * & & & \\
\hline & Aphaenogaster barbigula Wheeler & * & & & \\
\hline & Colobostruma cerornata Brown & * & $*$ & & \\
\hline & Crematogaster cornigera gp. JDM sp.126 & & & & * \\
\hline & Crematogaster dispar Forel & * & & & \\
\hline & Crematogaster frivola Forel & & * & & \\
\hline & Crematogaster queenslandica gp. JDM sp. 428 & * & & & \\
\hline & Crematogaster queenslandica gp. JDM sp. 1099 & & & * & \\
\hline & Crematogaster queenslandica gp. JDM sp. 1100 & & & * & \\
\hline & Crematogaster JDM sp. 859 & * & * & & \\
\hline & Epopostruma quadrispinosa (Forel) & & * & & \\
\hline & Meranoplus dichrous Forel & & * & & \\
\hline & Meranoplus fenestratus Smith & * & & & \\
\hline & Meranoplus JDM sp. 74 & & & & $*$ \\
\hline & Meranoplus JDM sp. 423 & * & * & & \\
\hline & Meranoplus JDM sp. 424 & * & & & \\
\hline & Meranoplus JDM sp. 679 & & * & & \\
\hline & Meranoplus JDM sp. 866 & * & & & \\
\hline & Meranoplus JDM sp. 1071 & & * & & \\
\hline
\end{tabular}


Table 3 (cont.)

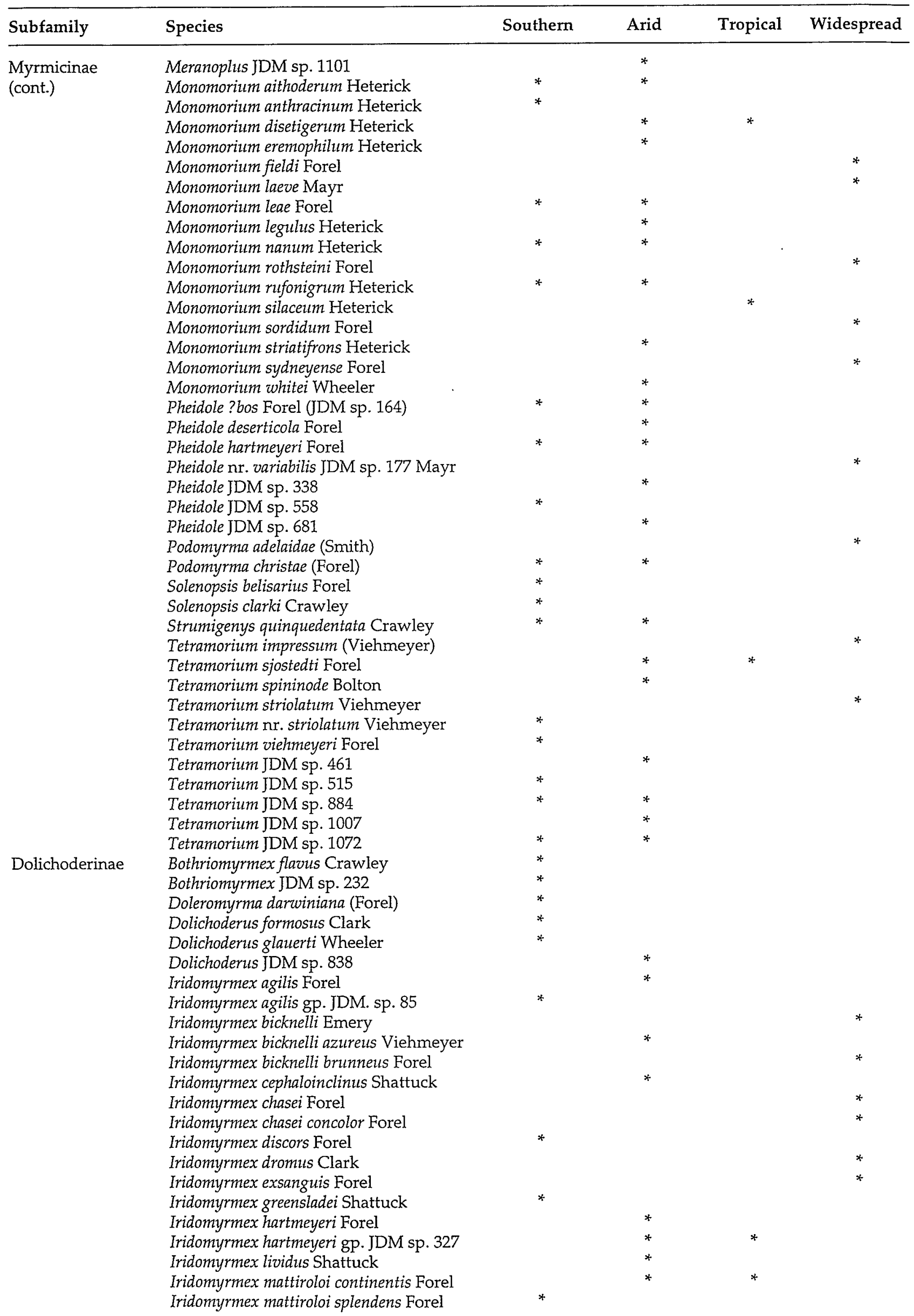


Table 3 (cont.)

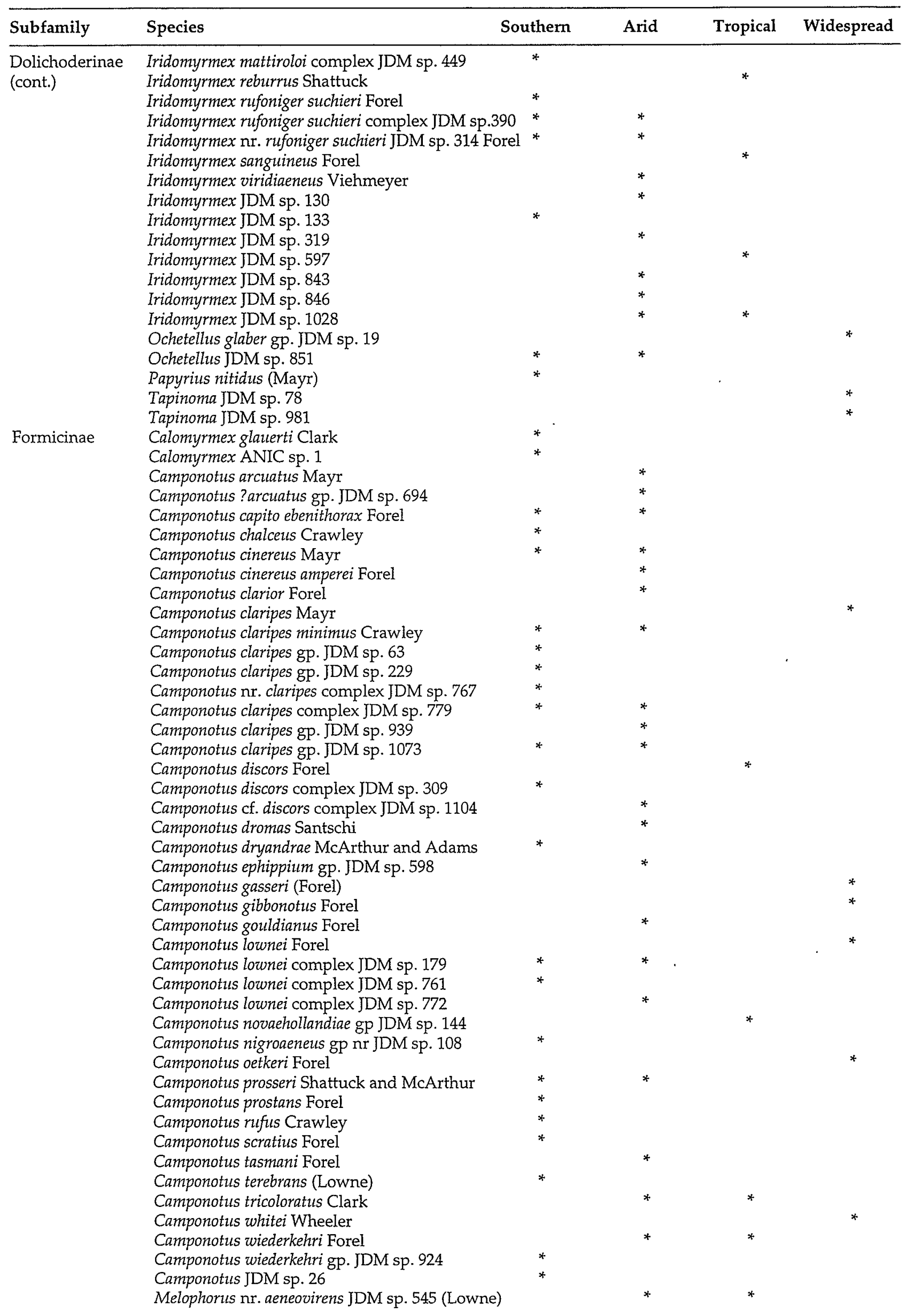


Table 3 (cont.)

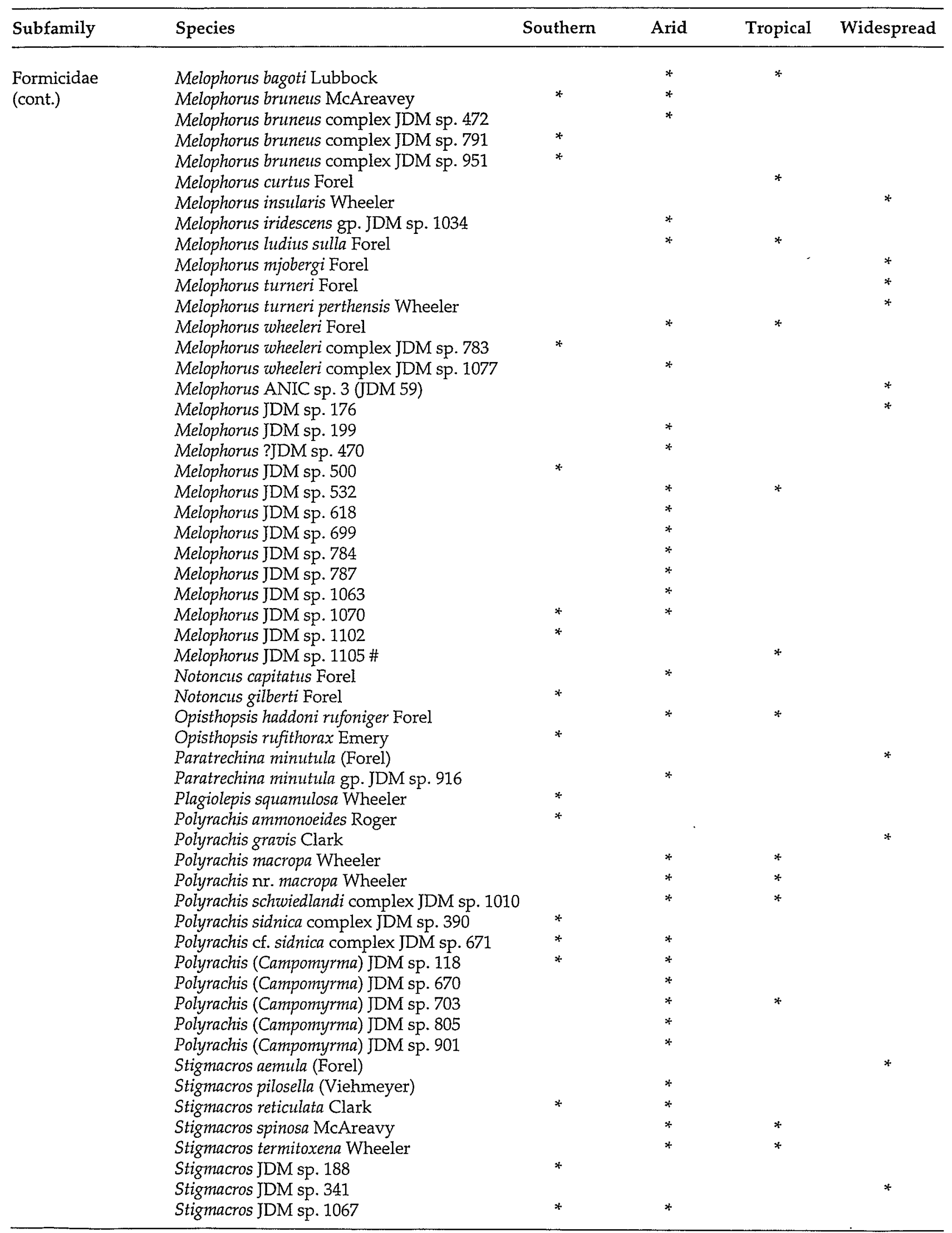

were based on distribution patterns apparent from the current study. The terms used were - southern, for species occurring in the SWBP; arid zone, for ants in this study not found in the SWBP; and tropical, for ants that are also found in the tropical regions of WA. Ants were listed as widespread if they fell into all three of the above categories. It should be stressed that these categories do not 
represent formal biogeographic origins of the species; they are provided to give an indication of the possible origin of the SCB fauna.

\section{Numerical and statistical analyses}

Distribution of the ant species was analysed in two ways. The first investigated the co-occurrence of species at any one quadrat using a 'two-step' association measure (Belbin 1980). The second method looked at ant species composition in each quadrat compared with every other quadrat using a Czekanowski association measure. The relationships between the species and the quadrats were then displayed as dendrograms using the 'unweighted pair group arithmetic averaging' (UPGMA) hierarchical clustering strategy (Sneath and Sokal 1973). From these dendrograms, a clustering parameter was identified and a two-way table constructed to show the assemblages of ants in relation to the groups of quadrats.

Relationships between physical and biological variables were explored to determine environmental factors that were significantly associated with ant species distribution. Eleven climatic variables recorded from ANUCLIM (McMahon et al. 1995) and 17 soil and geomorphic attributes were derived from sub-samples collected at a depth of 5-10 cm from 20-30 regularly dispersed points at each quadrat. Kruskal-Wallis Ksample tests were used to explore relationships between the species assemblages and the environmental variables. All data were analysed using PATN, a numerical analysis program developed to show patterns in species distribution (Belbin 1993).

Species data for individual quadrats were bulked within each survey area and analysed to explore patterns of ant composition that may have been clouded by the quadrat analysis. This was then repeated for genera to expose any differences between species and genus analyses. The same twostep procedure was utilised, resulting in dendrograms showing groups of survey areas with similar species and genus compositions.

The survey area groups were compared to environmental factors using the same KruskalWallis tests mentioned above. Eleven of the 17 climatic variables and 4 geographic variables (latitude, longitude, altitude and distance from the coast) were averaged for each survey area and utilised. The remaining soil and geomorphologic factors were deemed too variable to average for each survey area and were not used in the analysis.

\section{RESULTS}

\section{Species identification}

The study yielded 35 genera and 243 species of ants (Table 3) producing ant species new to the Curtin University Ant Collection and range extensions for a number of ants previously not thought to be in WA or formerly thought to be confined to the SWBP. Fifty eight percent of the species could be positively identified, with the remaining placed into species complexes and assigned ANIC or JDM numbers.

The most speciose genus was Camponotus, with 42 species, while Iridomyrmex and Melophorus followed close behind, with 31 and 30 respectively. Melophorus ludius sulla was the most ubiquitous ant, as it was found at 40 of the 61 quadrats studied, though it was not present at any BB quadrat. Three species of Iridomyrmex (I. chasei, I. chasei concolor and I. dromus) and two other Melophorus species (M. ANIC sp. 3 and $M$. JDM sp. 176) were some of the more common ants but Camponotus gibbonotus was the only species found at all 12 survey areas.

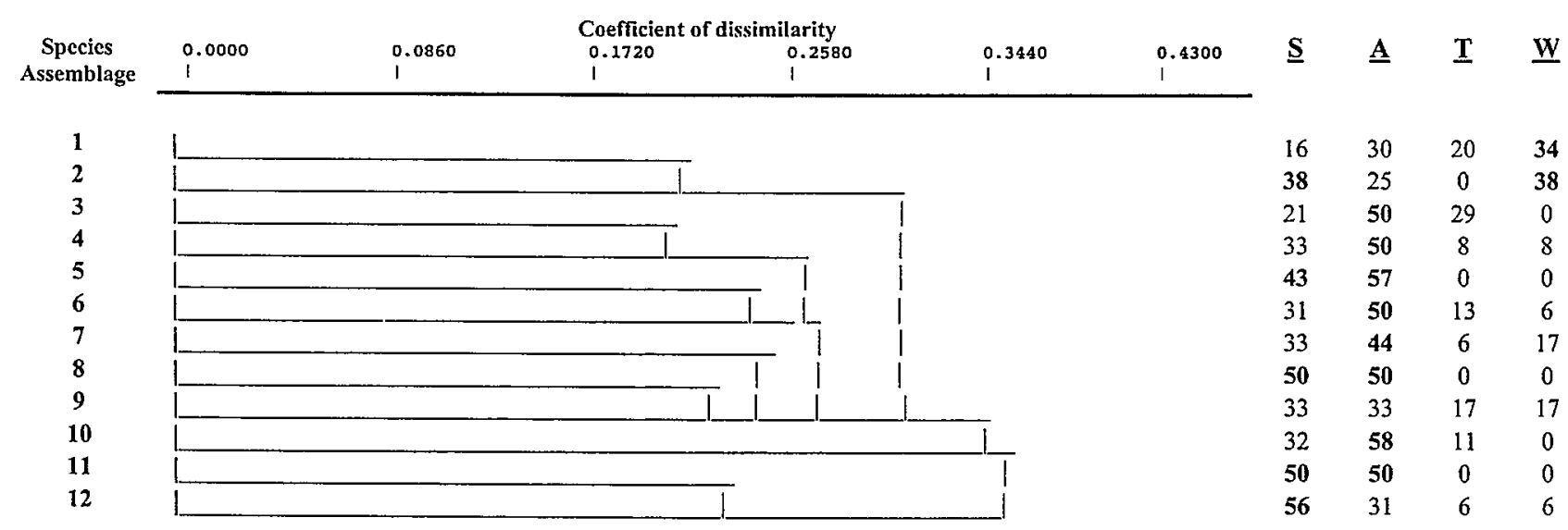

Figure 2 Dendrogram showing ant species assemblages according to similarity of distribution. The percentages of species in each phytogeographical region for each of the 12 assemblages are also displayed. Percentages greater than $33 \%$ are highlighted and used to depict the predominant biogeographic affiliations of each assemblage ( $\mathrm{S}=$ southern, $\mathrm{A}=$ arid zone, $\mathrm{T}=$ tropical, $\mathrm{W}=$ widespread). 
Table 4 List of all species that occurred at only one quadrat throughout the whole study area. The location of each quadrat is shown in Figure 1. These species were considered 'unique' and were not included in any analyses of data as it cannot be determined whether their occurrence in a particular quadrat was accidental (tourist) or whether the species was actually found in the area (resident).

\begin{tabular}{|c|c|c|c|c|c|}
\hline Subfamily & Species & Quadrat & Subfamily & Species & Quadrat \\
\hline \multirow[t]{7}{*}{ Myrmeciinae } & Myrmecia elegans & NE3 & \multirow{3}{*}{$\begin{array}{l}\text { Dolichoderinae } \\
\text { (cont.) }\end{array}$} & Iridomyrmex rufoniger suchieri complex JDM sp. 390 & $\mathrm{CU} 2$ \\
\hline & Myrmecia ?elegans & NE4 & & Iridomyrmex nr. rufoniger suchieri JDM sp. 314 & NE4 \\
\hline & Myrmecia hilli & KE2 & & Iridomyrmex JDM sp. 843 & GJ4 \\
\hline & Myrmecia urens gp. JDM sp. 1 & CU5 & \multirow[t]{4}{*}{ Formicinae } & Camponotus arcuatus & MR3 \\
\hline & Myrmecia nr. urens gp. JDM sp. 71 & ZU3 & & Camponotus ?arcuatus gp. JDM sp. 694 & CU5 \\
\hline & Myrmecia urens gp. JDM sp. 728 & ZU3 & & Camponotus capito ebenithorax & KE4 \\
\hline & Myrmecia sp. nr pilosula & PE5 & & Camponotus chalceus & ZU2 \\
\hline \multirow[t]{3}{*}{ Cerapachyinae } & Cerapachys JDM sp. 741 & WO3 & & Camponotus cinereus amperei & NE4 \\
\hline & Cerapachys JDM sp. 1049 & MD5 & & Camponotus nr. claripes complex JDM sp. 767 & $\mathrm{KE} 4$ \\
\hline & Cerapachys JDM sp. 1103 & NA5 & & Camponotus claripes complex JDM sp. 779 & MR5 \\
\hline \multirow[t]{5}{*}{ Ponerinae } & Leptogenys nr. tricosa JDM sp. 1021 & MR5 & & Camponotus claripes gp. JDM sp. 939 & MD3 \\
\hline & Pachycondyla denticulata gp. JDM sp. 730 & NE1 & & Camponotus claripes gp. JDM sp. 1073 & $\mathrm{BO} 3$ \\
\hline & Rhytidoponera dubia gp. JDM sp. 904 & BB1 & & Camponotus discors complex JDM sp. 309 & CU2 \\
\hline & Rhytidoponera metallica gp. JDM sp. 1097 & NA3 & & Camponotus dromas & NE5 \\
\hline & Rhytidoponera JDM sp. 736 & KE3 & & Camponotus dryandrae & KE3 \\
\hline \multirow[t]{19}{*}{ Myrmicinae } & Anisopheidole antipodum & NA4 & & Camponotus ephippizım gp. JDM sp. 568 & NE2 \\
\hline & Crematogaster cornigera gp. JDM sp.126 & NE1 & & Camponotus gasseri & ZU2 \\
\hline & Epopostruma quadrispinosa & MD3 & & Camponotus gouldianus & BB2 \\
\hline & Meranoplus dichrous & BB1 & & Camponotus lownei complex JDM sp. 179 & PE2 \\
\hline & Meranoplus fenestratus & NE5 & & Camponotus novaehollandiae gp JDM sp. 144 & MD3 \\
\hline & Meranoplus JDM sp. 423 & MR5 & & Camponotus prostans & $\mathrm{BO} 5$ \\
\hline & Meranoplus JDM sp. 866 & NA4 & & Camponotus whitei & NE2 \\
\hline & Meranoplus JDM sp. 1071 & NA4 & & Camponotus wiederkehri gp. JDM sp. 924 & KE1 \\
\hline & Monomorium aithodertım & NA3 & & Camponotus JDM sp. 26 & NE3 \\
\hline & Monomorium anthracinum & BB3 & & Melophorus bruneus complex JDM sp. 791 & $\mathrm{MD} 4$ \\
\hline & Monomorium silaceum & MD3 & & Melophorus curtus & MR3 \\
\hline & Monomoritum whitei & $\mathrm{BB} 1$ & & Melophorus iridescens gp. JDM sp. 1034 & MD1 \\
\hline & Pheidole JDM sp. 338 & MR3 & & Melophortus JDM sp. 532 & GJ1 \\
\hline & Pheidole JDM sp. 681 & KE3 & & Melophorus JDM sp. 618 & KE3 \\
\hline & Podomyrma adelaidae & ZU3 & & Melophorus JDM sp. 787 & NE1 \\
\hline & Podomyrma christae & NE1 & & Melophorus JDM sp. 1070 & G]3 \\
\hline & Strumigenys quinquedentata & CU6 & & Melophorus JDM sp. 1105 & NE4 \\
\hline & Tetramorium nr. striolatum & WO5 & & Opisthopsis rufithorax & NE4 \\
\hline & Tetramorium JDM sp. 1072 & KE4 & & Papyrius nitidus & ZU5 \\
\hline \multirow[t]{7}{*}{ Dolichoderinae } & Bothriomyrmex flavus & ZU2 & & Polyrachis nr. macropa & GJ4 \\
\hline & Bothriomyrmex JDM sp. 232 & NA3 & & Polyrachis (Campomyrma) JDM sp. 118 & ZU1 \\
\hline & Dolichoderus formosus & NE4 & & Polyrachis (Campomyrma) JDM sp. 703 & PE3 \\
\hline & Dolichoderus glauerti & NA2 & & Polyrachis (Campomyrma) JDM sp. 901 & KE1 \\
\hline & Iridomyrmex agilis gp. JDM sp. 85 & NA3 & & Stigmacros pilosella & MD3 \\
\hline & Iridomyrmex exsanguis & KE3 & & & \\
\hline & Iridomyrmex reburrus & BB1 & & & \\
\hline
\end{tabular}




\section{Biogeographic distribution}

There were a number of species that were placed in more than one biogeographic region (BR). There were 34 species that traversed both the southern and arid zones and 22 that spanned arid and tropical zones. A number of species (43) were considered widespread, i.e. found in all three BR's. The majority of species found in the study area were arid in distribution (Figure 2).

\section{Species richness and assemblage composition}

Eighty-one 'unique' species removed from the data matrix are listed in Table 4 . The quadrats MR5 and ZU3 yielded the greatest number of species, with 45 in each; NE4 followed as a close second with 44 species. Overall, Nerren Nerren survey area (NE) had the highest record of species, a total of 89 . 'Uniques' did not make up large proportions of most of the quadrats' total species, but KE3 and MD3 had up to $20 \%$ of their species only occurring there. The Nerren Nerren survey area had the highest number of 'uniques' out of all the survey areas, with $18 \%$ of its total species occurring only there.

The PATN analysis of the species data yielded a two-way table that grouped the species into 12 assemblages (Table 5). These assemblages were then associated with the quadrats to reveal eight quadrat groupings. These eight quadrat groups are displayed in Figure 3 as a dendrogram, showing the measure of dissimilarity between quadrat groups.

Assemblage 1 appeared to be a large mix of species, possessing no particular association with any quadrat group. All the other assemblages demonstrated some degree of clustering within one or two quadrat groups. Assemblage 2 had a majority of species falling into quadrat Group 4, which was characterised as being near coastal sand dunes and plains'; the assemblage was classified as mostly southern and widespread in biogeographic affinities.

Assemblage 3 had close associations with the same quadrat group, though the majority of the assemblage had an arid zone distribution and contained more tropical representatives than southern. Assemblage 3 had a weak clustering in Group 5, which was composed of only NE quadrats, two of which were in the SWBP. This variability in the $\mathrm{NE}$ environment is demonstrated by Assemblage 5, which has an almost equal balance of arid zone and southern species (Figure 2).

Assemblage 8 was unique within the assemblages in that it contained only two species of ant, which were present only within Group 6 quadrats. The geomorphologic characteristic of these quadrats was 'samphire bushland,' and these were the only sites in the study area with this feature. These two ants, Cerapachys gilesi and Melophorus wheeleri

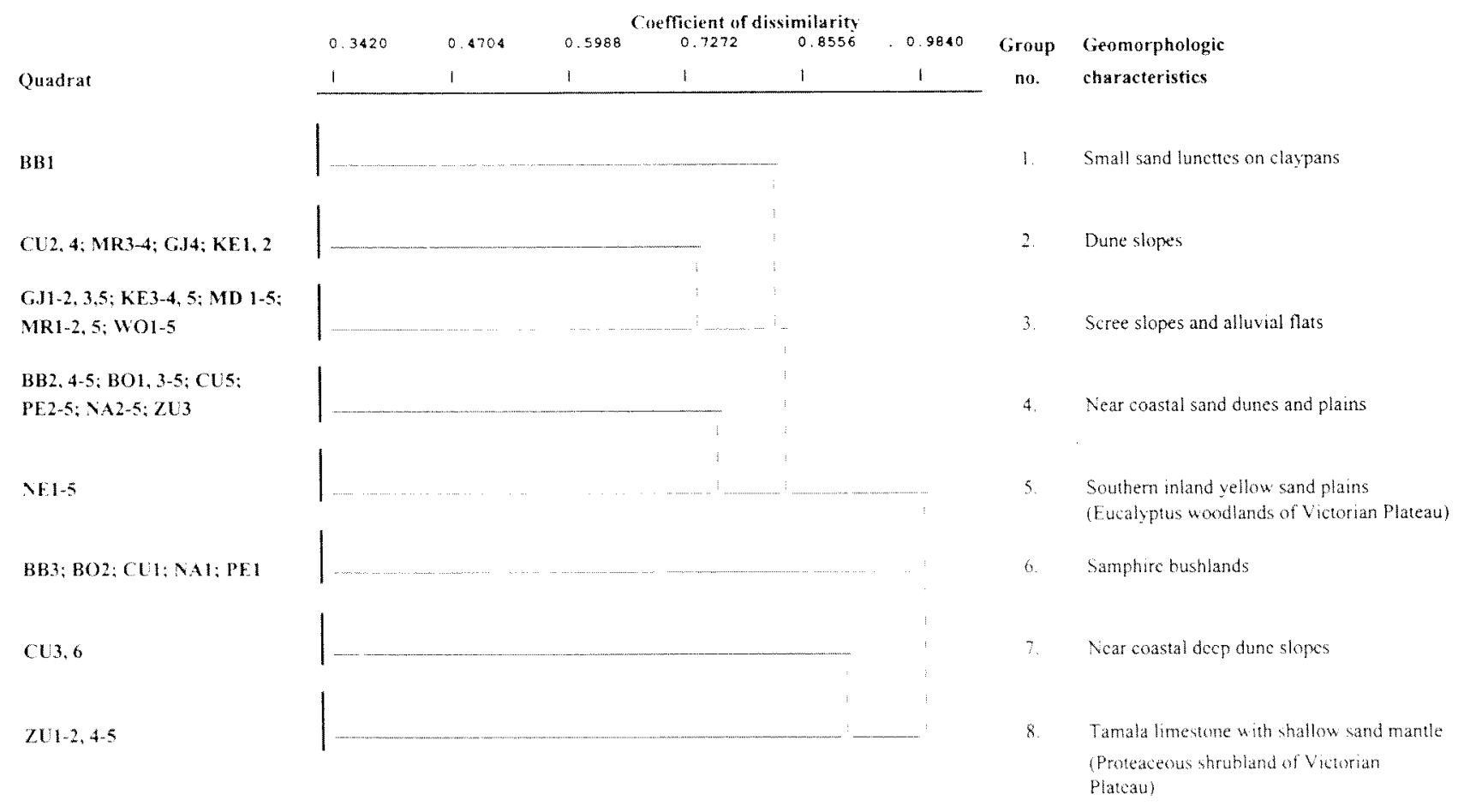

Figure 3 Dendrogram showing the groupings of quadrats according to similarity of species composition, based upon the two-way table generated by the species co-occurrence matrix (Table 4). The cut-off for the degree of dissimilarity between sites was set at 0.7272 . If a dendrogram line did not meet this cut-off point, the quadrats were considered too dissimilar to be grouped together. Brief characteristics of the grouped quadrats are displayed in the final column; the location of each quadrat is shown in Figure 1 
Table 5 Two-way table showing the quadrats grouped according to the 12 species assemblages. Unique species have been removed from the matrix. Each asterisk represents a species occurrence at that quadrat, the locations of which are shown in Figure 1 . A dark highlighted box contains $>40 \%$ of species in that assemblage; lighter highlighted boxes contain an additional $30 \%$ of species; unhighlighted boxes contain the remaining species.

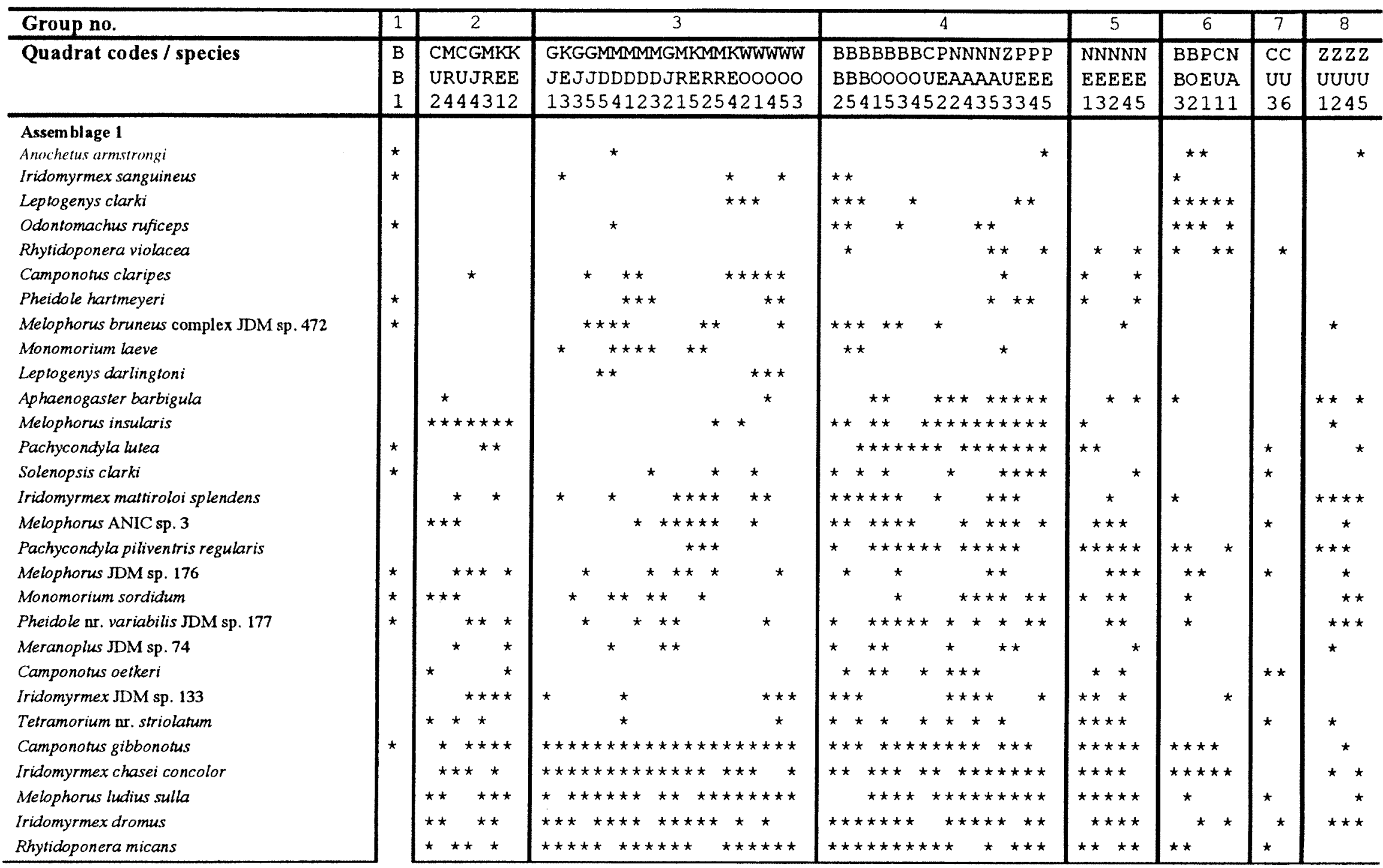




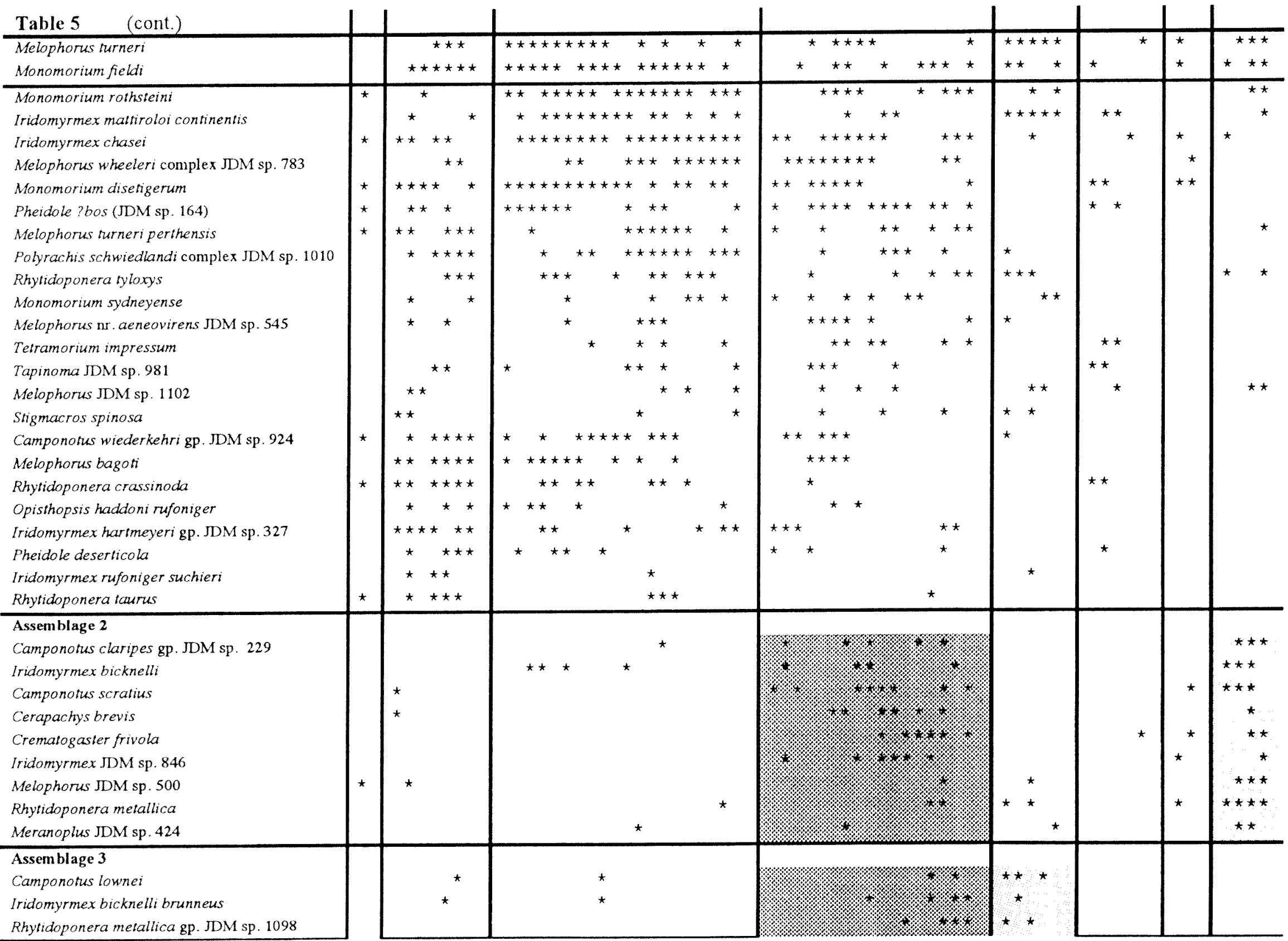




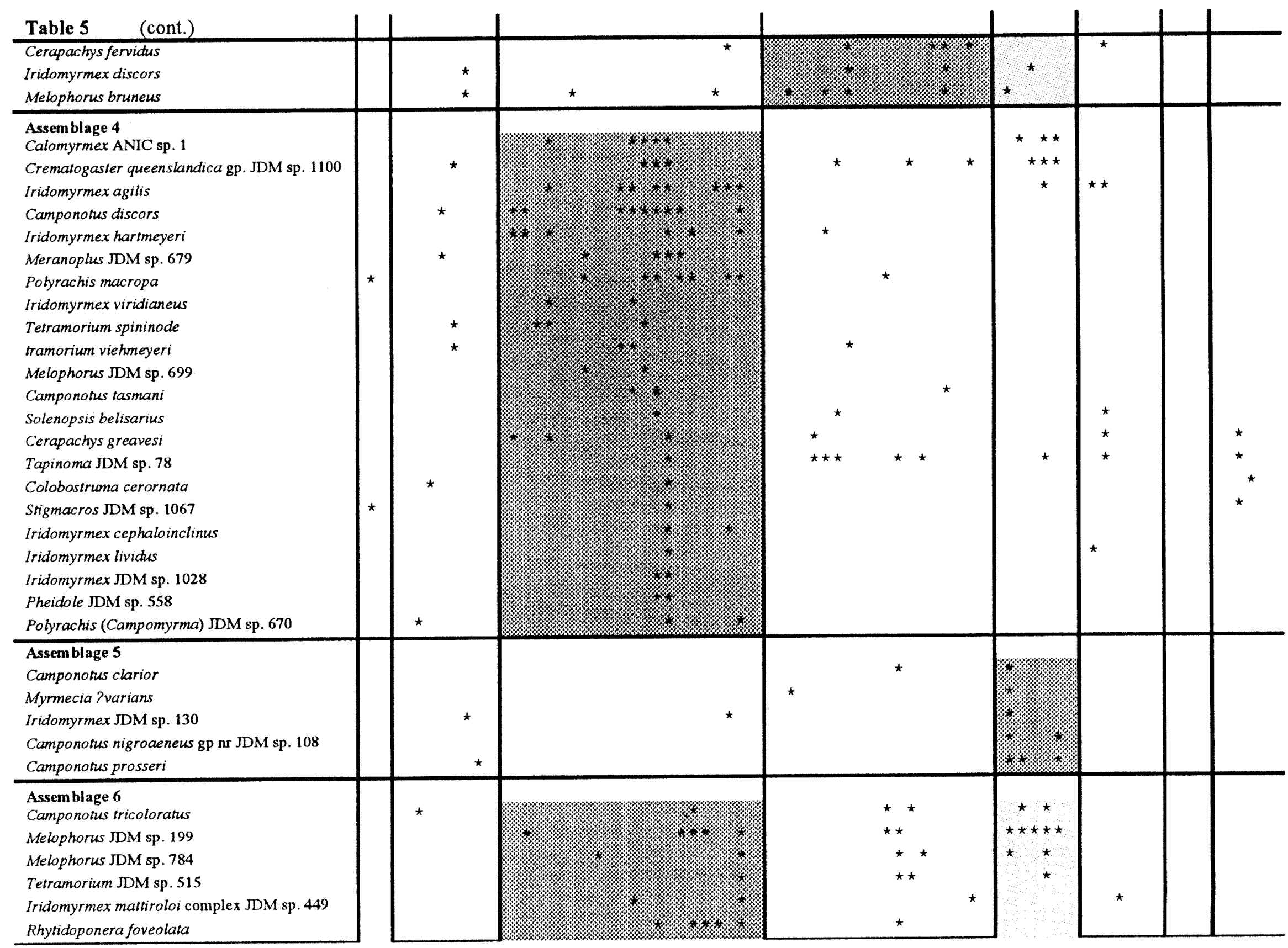




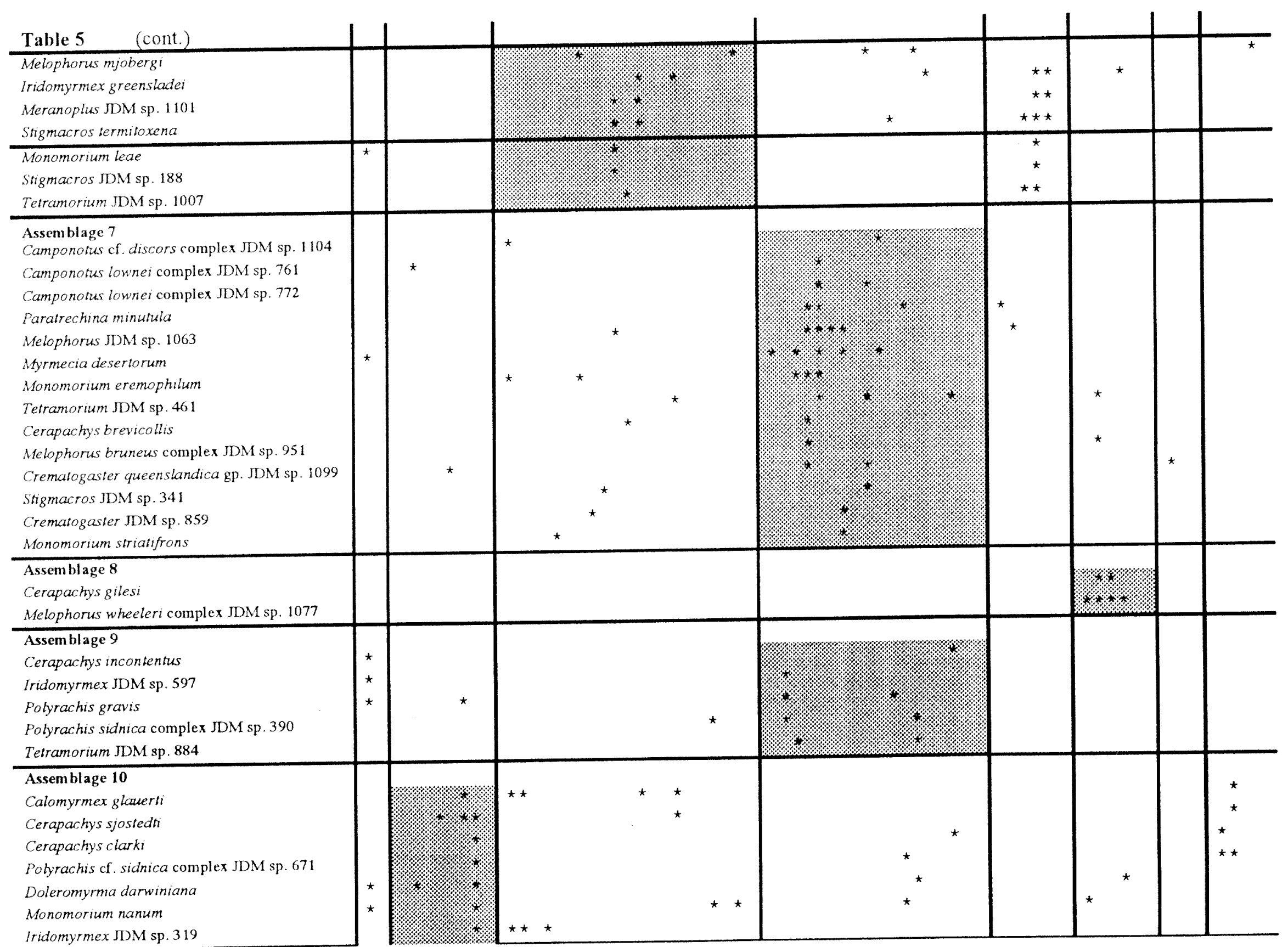




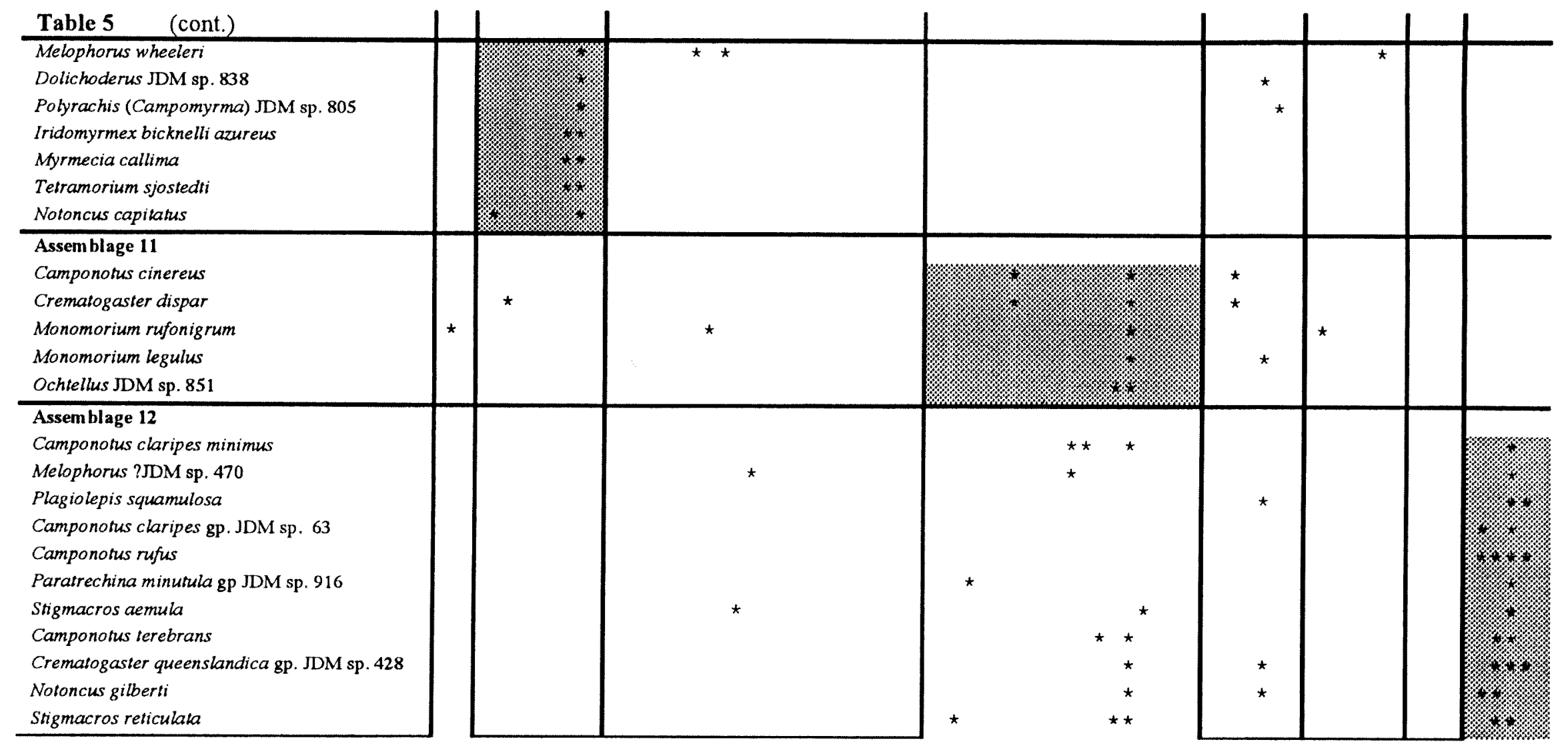


a) Species by survey area

\begin{tabular}{|c|c|c|c|c|c|c|c|c|}
\hline & \multicolumn{6}{|c|}{ Coefficient of dissimilarity } & \multirow{3}{*}{$\begin{array}{c}\text { Group } \\
\text { no. }\end{array}$} & \multirow{3}{*}{$\begin{array}{l}\text { General } \\
\text { characteristics }\end{array}$} \\
\hline & 0.3380 & 0.3886 & 0.4392 & 0.4898 & 0.5404 & \multirow{2}{*}{$\begin{array}{c}0.5910 \\
1\end{array}$} & & \\
\hline Survey area & 1 & 1 & 1 & 1 & 1 & & & \\
\hline $\mathrm{BB}, \mathrm{CU}$ & & & & 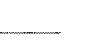 & & & 1. & Coastal northern \\
\hline BO, MD, MR, NA, PE, WO & & & & 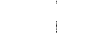 & 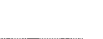 & & 2 & Near coastal \\
\hline & & & & & & & & \\
\hline GI, KE & & & & & 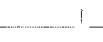 & $\ldots$ & 3. & Central inland \\
\hline NE & & & $\ldots$ & & & & 4. & Southem inland \\
\hline & & & & & 1 & $!$ & 5 & Coactal couthern \\
\hline \multicolumn{9}{|l|}{ b) Genus by survey area } \\
\hline & \multicolumn{6}{|c|}{ Coefficient of dissimilarity } & \multirow{3}{*}{$\begin{array}{c}\text { Group } \\
\text { no. }\end{array}$} & \multirow{3}{*}{$\begin{array}{l}\text { General } \\
\text { characteristics }\end{array}$} \\
\hline & 0.0698 & 0.1204 & 0.1711 & 0.2217 & 0.2724 & 0.3230 & & \\
\hline Survey area & 1 & 1 & 1 & 1 & 1 & 1 & & \\
\hline BB,BO,NA,MD,PE & & & & & & & 1. & Coastal \\
\hline CU,KE,MR & & & & & 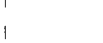 & & 2 & Northem \\
\hline & & & & & & 1 & & \\
\hline G.J.WO & $\ldots$ & te & . & 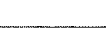 & + & 1 & 3. & Central inland \\
\hline $\mathrm{NE}, Z \mathrm{U}$ & & & & & & 1 & 4. & Southern \\
\hline
\end{tabular}

Figure 4 Dendrograms showing the groupings of survey areas according to similarity of a) species composition and b) genus composition, based upon two-way tables generated by the species/genus co-occurrence matrix for each survey area. Brief generalisations of the grouped survey areas are displayed in the final column.

complex JDM sp.1077 are very different in that the former is a common ant around the Perth hinterland and the latter is more common in the drier arid zone regions to the north.

Both species have been recorded for the SWBP, but presumably it is the first time that both species have been associated together in the saline areas of samphire bushland. No other assemblage was associated with this group of quadrats.

Figure 4 a provides an analysis of the species in terms of survey areas, instead of individual quadrats. This revealed five groupings of survey areas on the basis of species. These survey area groups (numbered clouds) are displayed in Figure $5 \mathrm{a}$, which reveals a separation of north and south faunas (clouds 1 and 3: 4 and 5), as well as inland and coastal assemblages (clouds 1: 3 and 4: 5). This pattern was further simplified in Figure $4 b$, where ant genera analysed against the survey areas revealed a slightly different association of survey areas. The survey area groups in Figure $5 b$ further emphasize a more north-south separation (clouds 2 : 4).

\section{Environmental variables}

The environmental parameters revealed some correlations with the patterns of distribution in terms of species, as well as with genera. Regarding the 12 species assemblages, almost all environmental variables were significantly associated $(P>0.05)$ except for stoniness, over-bank stream flow and soil exchangeable sodium. The environmental variables associated with the survey area groups revealed some clearer patterns. There appeared to be a pattern relating species distribution to maximum temperature, precipitation

Table 6 The climatic and geographical variables associated with the 5 survey area groups generated by the species assemblages and 4 survey area groups generated by the genera assemblages. Only significant values $(P<$ $0.05)$ revealed by a Kruskal-Wallis Test are given

a) Species by survey area

\begin{tabular}{ll}
\hline Environmental variable & $P$ \\
\hline Maximum warmest period temperature & .048 \\
Temperature annual range & .056 \\
Warmest quarter temperature & .029 \\
Annual average precipitation & .025 \\
Wettest quarter precipitation & .049 \\
Coldest quarter precipitation & .033 \\
Altitude & .006 \\
Longitude & .050 \\
Coastal Distance & .023 \\
\hline
\end{tabular}

b) Genus by survey area

\begin{tabular}{ll}
\hline Environmental variable & $P$ \\
\hline Annual average temperature & .009 \\
Warmest quarter temperature & .046 \\
Coldest quarter temperature & .034 \\
Annual average precipitation & .050 \\
Warmest quarter precipitation & .037 \\
Coldest quarter precipitation & .043 \\
Latitude .009 & \\
\end{tabular}




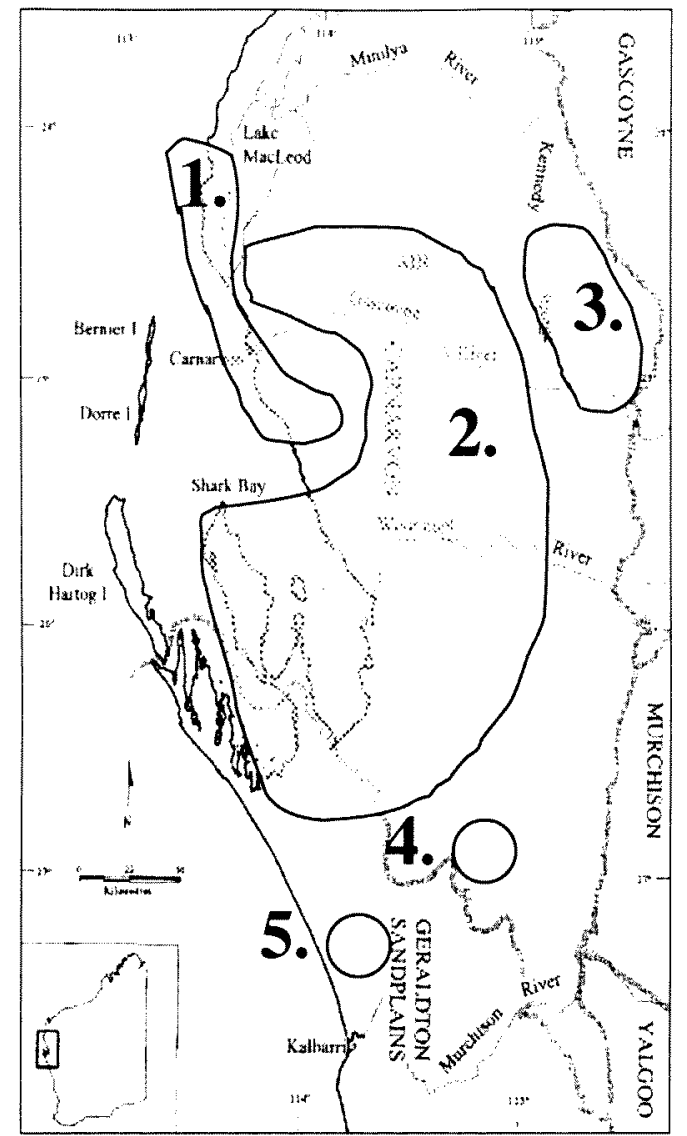

a) Species assemblage

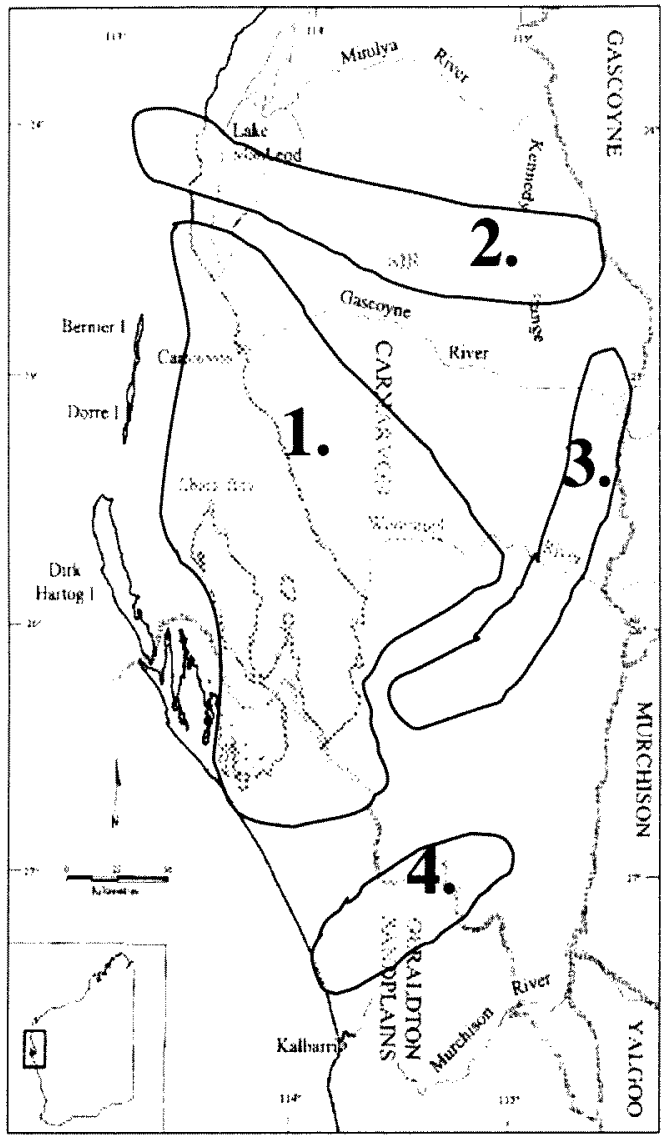

b) Genus assemblage

Figure 5 The southern Carnarvon Basin study area. Each shaded cloud shows the groupings of survey areas exhibiting similarities in terms of a) species assemblage and b) genus assemblage. The numbers on the clouds correspond to the survey area groups displayed in Figures $4 a$ and $b$.

during the wet season, altitude, longitude and coastal distance. This was reflected somewhat in the genus assemblages, showing an association with temperature, precipitation and latitude (Table 6).

These associations with environmental variables for survey areas reflect the patterns seen in Figures $5 a$ and $b$. The differences between species assemblages and genus assemblages are characterised by the fact that the species assemblages are separated by altitude, longitude and coastal distance, while genus assemblages were separated by latitude. Figure 5 a shows a separation from coastal areas to inland, and from lowland to highland, whereas Figure $5 b$ demonstrates a separation from north to south, with less of a coastal to inland separation.

\section{DISCUSSION}

\section{Biogeography}

The ants of the southern Carnarvon Basin are highly species rich, although some of the 243 species could not confidently be placed in any one biogeographic region; overall there was a greater tendency for species to have an arid zone distribution than a southern one, and much less a tropical or widespread distribution. The overlap between arid zone and southern elements of this study demonstrates the transitional nature of this area.

A majority of the ant species are represented in the SWBP, with a number of them being present at the limit of their ranges in the southern two survey areas, ZU and NE. Gibson et al. (2000) suggest that the phytogeographic boundary established by Beard should be located more to the south and to the west in order to exclude some of the arid vegetation types found around Shark Bay. This is supported by the fact that the NA survey area (technically located in the SWBP) was grouped with the more northern survey areas, in contrast with $\mathrm{ZU}$. The species assemblage at $\mathrm{NE}$ also contains fauna that are considered more arid zone, suggesting that both these sites should not be included in the SWBP. If the SWBP boundaries were moved more southerly and westerly, this would better account for the species occurrence at these two sites.

Nerren Nerren was unusual in that its quadrats spanned the phytogeographic boundary between the south-west and arid regions. It contained a high 
number of uniques, which corresponds with the fact that NE2 fell into its own individual vegetation grouping, that also appeared to be a transitional area. This site may be of great ecological importance in terms of investigating flora and fauna that have adapted to the variable nature of the area.

\section{Patterns of association related to environmental variables}

Climate appears to play a prominent role in the distribution of the ant species. Both the quadrat and survey area analyses showed significant associations with temperature and rainfall. Although the quadrat analyses demonstrated significance for all climatic variables, the survey area data were able to give more specific associations such as with temperature. Ants have been positively correlated with temperature in other studies (Briese and Macauley 1981, Vanderwoude et al. 1997), which demonstrates their relation to vegetation and to soils; both these factors would heavily influence ant species distribution (Greenslade and Thompson 1981, Morton 1982 , Andersen 1993).

While Gibson et al. (2000) found that the vegetation boundaries were highly correlated with edaphic factors, (supporting their suggestion to move the phytogeographical boundary) the ant species assemblages did not seem to focus on any particular soil factor. Lobry De Bruyn (1999) suggests that ants are good soil quality indicators in natural and rural environments. Although the results from this current study support this idea, the broad base and wide range of the research area may have clouded any particular soil factor associations that could be derived from the ant species distribution

Rainfall was also positively associated with the ant species assemblages. There is an increasing amount of variability in mean precipitation moving northwards in the study area, due to irregularity of summer monsoonal rainfall. This trend is reversed in the more southern areas, which are subject to regular winter rains. The separation of southern and northern faunas reflects these precipitation differences, which may be further enhanced by the coastal - inland differences in rainfall volume. Rainfall, or lack of, can influence ant species distribution to a great degree. For example, it results in a more Iridomyrmex - dominated landscape in the arid areas and more cryptic species in wetter areas (Greenslade 1985). While species abundance was not measured, the current study demonstrates a more Camponotus / Melophorus dominated landscape.

The nature of the species composition observed in this study supported the two major groups of ant genera established by Greenslade and Greenslade (1989). Based on broad ecological and geographical trends, they separated the 'core' groups of ants (Group I: Iridomyrmex, Melophorus and Camponotus) from the other more specialised genera (Group II) such as Monomorium, Pheidole and Rhytidoponera. Using data derived from different eastern states' studies, they hypothesized that high competition from Group I species would reduce species diversity of Group II species, but in situations where the ratio of Groups $\mathbf{I} / \mathbf{I I}$ is low, the high diversity may be due to areas being in transition zones where Group I taxa are outside their climatic optima. This theory is supported by results of this study, as it shows that there is a relatively low ratio between the Group I species (103 spp.) and Group II species (89 spp.).

Wyrwoll et al. (2000a) also found that there was a more pronounced north - south gradient for mean coldest quarter temperature, which is in concordance with the genus assemblages generated for the survey areas. Table $6 b$ shows that there is a significant association between genus assemblages and coldest quarter temperature; Figure $5 b$ further demonstrates this, showing that the assemblages display a more north - south separation of survey area groups. Recent studies have found that species richness in ants can be related to latitudinal gradients, even at small scales (Gotelli and Ellison 2002). Though the current study site spanned roughly only four latitudinal degrees, latitude was significantly associated with the genus assemblages (Table 6b). While species assemblages did not have a significant association with latitude, perhaps a further study of species richness may generate a relationship. It would be of interest to see whether genus to species ratios can be made more predictive over smaller latitudinal gradations.

Overall, there is a difference between species and genus assemblages; the former closely follows vegetational patterns, while the latter tends towards latitudinal gradients. Genus richness has been found to be an inadequate indicator of species richness, as there is a high amount of variability in species to genus ratio, depending on the region (Andersen 1995). While the southern sites NE and $\mathrm{ZU}$ displayed a relatively lower ratio (i.e. similar numbers of species and genera) than the northern survey areas, NE separated out again in that it had a ratio more similar to the northern survey areas. This discrepancy also cropped up in the $\mathrm{CU}$ and $\mathrm{BO}$ survey areas, which also showed very low ratios. In this case, it appears that the species to genus ratio follows the trend found in southern semi-arid zones and northern semi-arid zones, where the mixing of genera (cool temperate genera from the south and tropical genera from the north) causes a lower ratio (Andersen, 1995). This lends further support to the fact that this area is a major transitional zone, which therefore should be taken into consideration as a biogeographically and ecologically significant area. 
The general ant species distribution appears to follow the modified phytogeographic zones suggested by Gibson et al. (2000), but further studies on individual species would be required in order to establish ranges and provide a concrete basis for determining biogeographic origin. This study contributes to a growing pool of data that can be used to compile a complete bio-inventory of all ant species for Western Australia.

\section{ACKNOWLEDGEMENTS}

The authors wish to thank Mark Harvey for making available the material from WAM and for providing information on the preliminary sorting of invertebrates that had already been carried out. To Brian Heterick, who assisted in identification and verification of species, as well as commenting on an earlier draft of this manuscript. To Norm McKenzie, for making himself available for the statistical analyses and also for providing comments on an earlier draft. Thanks also, to all those involved in the field collection of the biological and physical information utilised in this study. Funding for this project was provided by the Commonwealth through the National Reserves System Co-operative Program of the Australian Nature Conservancy (now Environment Australia), together with State funds provided by the DCLM and WAM.

\section{REFERENCES}

Alonso, L. E. 2000. Ants as indicators of diversity. Pages 80-88 in Agosti, D., Majer, J. D., Alonso, L. E. and Schultz, T. R. editors. Ants: Standard methods for measuring and monitoring biodiversity. Smithsonian Institution Press, Washington, D.C.

Andersen, A. N. 1993. Ant communities in the Gulf Region of Australia's semi-arid tropics: Species composition, Patterns of organisation, and Biogeography. Australian Journal of Ecology 41: 399414.

Andersen, A. N. 1995. Measuring more of biodiversity: Genus richness as a surrogate for species richness in Australian ant faunas. Biological Conservation 73: 3943.

Andersen, A. N. 1997. Functional groups and patterns of organisation in North American ant communities: a parallel with Australia. Journal of Biogeography 24: 433460.

Andersen, A. N., and Burbidge, A. H. 1992. An overview of the ant fauna of Cape Arid National Park, Western Australia. Journal of the Royal Society of Western Australia 75: 41-46.

Belbin, L. 1980. TWOSTEP: a program incorporating asymmetric comparisons that uses two steps to produce a dissimilarity matrix. Technical Memorandum 80/9. CSIRO, Division of Land Use Research, Canberra, ACT.

Belbin, L. 1993. PATN: pattern analysis package. CSIRO, Canberra, ACT.
Bolton, B. 2003. Synopsis and classification of Formicidae. Memoirs of the American Entomological Institute 71: 1370.

Briese, D. T., and Macauley, B. J. 1981. Food collection within an ant community in semi-arid Australia, with special reference to seed harvesters. Australian Journal of Ecology 6: 1-19.

Burbidge, A. H., McKenzie, N. L. and Harvey, M. S. 2000. A biogeographic survey of the southern Carnarvon Basin, Western Australia: a background and methods. Pages 1-12 in Burbidge, A. H., Harvey, M. S. and McKenzie, N. L. editors. Biodiversity of the southern Carnarvon Basin. Western Australian Museum, Perth, WA.

Drake, W. E. 1981. Ant-seed interactions in dry schlerophyll forest on North Stradbroke Island, Queensland. Australian Journal of Botany 29: 293-310.

Fisher, B. L. 1999. Improving inventory efficiency: a case study of leaf-litter ant diversity in Madagascar. Ecological Applications 9: 714-731.

Gibson, N., Burbidge, A. H., Keighery, G. J. and Lyons, M. N. 2000. The temperate to arid transition of the Irwin-Carnarvon phytogeographic boundary, Western Australia. Pages 155-174 in Burbidge, A. H., Harvey, M. S. and McKenzie, N. L. editors. Biodiversity of the southern Camarvon Basin. Western Australian Museum, Perth, WA.

Gotelli, N. J., and Ellison, A. M. 2002. Biogeography at a regional scale: Determinants of ant species density in New England bogs and forests. Ecology 83: 1604-1609.

Greenslade, P. J. M. 1985. Some effects of season and geographical aspects on ants (Hymenoptera : Formicidae) in the Mount Lofty Ranges, South Australia. Transactions of the Royal Society of South Australia 109: 17-23.

Greenslade, P. J. M., and Greenslade, P. 1989. Ground layer invertebrate fauna. Pages 266-284 in Noble, J. C. and Bradstock, R. A., editors. Mediterranean landscapes in Australia, Mallee ecosystems and their management. CSIRO Publications, Melbourne, VIC.

Greenslade, P. J. M., and Thompson, C. H. 1981. Ant distribution, vegetation and soil relationships in the Cooloola-Noosa River area, Queensland. Pages 192207 in Gillison, A. N. and Andersen, D. J., editors. Vegetation classification in Australia: Proceedings of a workshop sponsored by CSIRO Division of Land Use Research, Canberra, October 1978. Australian National University Press, Canberra, ACT.

Harvey, M. S., Sampey, A., West, P. J. and Waldock, J. M. 2000. Araneomorph spiders from the southern Carnarvon Basin, Western Australia: a consideration of regional biogeographic relationships. Pages 295 322 in Burbidge, A. H., Harvey, M. S. and McKenzie, N. L. editors. Biodiversity of the southern Carnarvon Basin. Western Australian Museum, Perth, WA.

Keighery, G. J., Gibson, N., Lyons, M. N. and Burbidge, A. H. 2000. Flora and vegetation of the southern Carnarvon Basin, Western Australia. Pages 77-154 in Burbidge, A. H., Harvey, M. S. and McKenzie, N. L. editors. Biodiversity of the southern Camarvon Basin. Western Australian Museum, Perth, WA.

Kremen, C., R. K. Colwell, T. L. Erwin, D. D. Murphy, R. F. Noss, and M. A. Sanjayan. 1993. Terrestrial 
arthropod assemblages: their use in conservation planning. Conserwation Biology 7: 796-808.

Lawton, J. H., Bignell, D. E., Bolton, B., Bloemers, G. F., Eggleton, P., Hammond, P. M., Hodda, M, Holt, R. D., Larsen, T. B., Mawdsley, N. A., Stork, N. E., Srivastava, D. S. and Watt, A. D. 1998. Biodiversity inventories, indicator taxa and effects of habitat modification in tropical forest. Nature (London) 391 : 72-76.

Lobry De Bruyn, L. A. 1999. Ants as bioindicators of soil function in rural environments. Agriculture, ecosystems and environment 74: 425-441.

Longino, J. T. 2000. What to do with the data. Pages 186203 in Agosti, D., Majer, J. D., Alonso, L. E. and Schultz, T. R. editors. Ants: Standard methods for measuring and monitoring biodiversity. Smithsonian Institution Press, Washington, D.C.

Majer, J. D., Shattuck, S. O., Andersen, A. N. and Beattie, A. J. 2004. Australian ant research: fabulous fauna, functional groups, pharmaceuticals, and the Fatherhood. Australian Journal of Entomology 43: XXX$X X X$ [In press].

McGeoch, M. A. 1998. The selection, testing and application of terrestrial insects as bioindicators. Biol. Rev. 73: 181-201.

McKenzie, N. L., Belbin, L., Margules, C. R. and Keighery, G. J. 1989. Selecting representative reserve systems in remote areas: A case study in the Nullarbor Region, Australia. Biological Conservation 50: 239-261.

McKenzie, N. L., Rolfe, J. K., Aplin, K., Cowan, M. and Smith, L. A. 2000. Herpetofauna of the southern Carnarvon Basin, Western Australia. Pages 335-360 in Burbidge, A. H., Harvey, M. S. and McKenzie, N. L. editors. Biodiversity of the southern Carnaroon Basin. Western Australian Museum, Perth, WA.

McMahon, J. P., Hutchinson, M. F., Nix, H. A and Ord, K. D. 1995. ANUCLIM Users Guide, Version 1. Centre for Resource and Environmental Studies, Australian National University, Canberra, ACT.

Morton, S. R. 1982. Granivory in the Australian arid zone: diversity of harvester ants and structure of their communities. Pages 257-262 in Barker, W. R. and Greenslade, P. J. M., editors. Evolution of the flora and fanma of arid Australia. Peacock Publications, Frewville, SA.
Oliver, I., and Beattie, A. J. 1993. A possible method for the rapid assessment of biodiversity. Conser. Biol. 7 : 562-568.

Oliver, I., and Beattie, A. J. 1996. Designing a costeffective invertebrate survey: a test of methods for rapid assessment of biodiversity. Ecol. Appl. 6: 594607.

Rossbach, M. H., and Majer, J. D. 1983. A preliminary survey of the ant fauna of the Darling Plateau and Swan Coastal Plain near Perth, Western Australia. Journal of the Royal Society of Western Australia 66: 8590.

Shattuck, S. O. 1999. Australian ants: Their biology and identification, First edition. CSIRO Publishing, Melbourne, VIC.

Sneath, P. H. A. and Sokal, R. R. 1973. Numerical Taxonomy. The principals and practice of numerical classification. W.H. Freeman, San Francisco, CA.

Stork, N. E., and Samways, M. J. 1995. Inventorying and Monitoring. Pages 459-461 in Heywood, V. H. and Watson, R. T., editors. Global Biodiversity Assessment. Cambridge University Press, Melboume, Australia.

Vanderwoude, C., Andersen, A. N. and House, P. N. 1997. Community organisation, biogeography and seasonality of ants in an open forest of south-eastern Queensland. Australian Journal of Ecology 45: 523-537.

Wyrwoll, K. H., Courtney, J. and Sandercock, P. 2000a. The climatic environment of the Carnarvon Basin, Western Australia. Pages 13-28 in Burbidge, A. H., Harvey, M. S. and McKenzie, N. L. editors. Biodiversity of the southern Carnarvon Basin. Western Australian Museum, Perth, WA.

Wyrwoll, K. H., Stoneman, T., Elliot, G. and Sandercock, P. 2000b. Geoecological setting of the Carnarvon Basin, Western Australia: geology, geomorphology and soils of selected sites. Pages 29-76 in Burbidge, A. H., Harvey, M. S. and McKenzie, N. L. editors. Biodiversity of the southern Carnarvon Basin. Western Australian Museum, Perth, WA.

Manuscript received 17 Febnary 2004; accepted 6 May 2004 